\title{
Duration and timing of reproduction in decapod crustaceans of the NW Mediterranean continental margin: is there a general pattern?
}

\author{
Joan B. Company*, Francisco Sardà, Pere Puig, Joan E. Cartes, Albert Palanques \\ Institut de Ciències del Mar (CSIC), Passeig Marítim de la Barceloneta 37-49, 08003 Barcelona, Catalonia, Spain
}

\begin{abstract}
To describe how decapod crustaceans are adapted to depth, the duration and timing of the reproductive periods of the 19 most abundant species were compared across the continental margin of the NW Mediterranean Sea. Reproductive activity centered on different seasons, depending on genus, but the deepest-dwelling species of this study, i.e. those living at depths from 600 to $>1000 \mathrm{~m}$, showed more seasonal reproductive activity than species dwelling in shallower waters, in which reproductive activity occurred year-round. Thus, in genera where 2 or more species were studied (Pasiphaea, Processa, Plesionika, Munida), the duration of the reproductive periods decreased with increasing depth distribution of congeneric species. This pattern was present in epi-mesopelagic, nektobenthic and benthic species. The only exception was the blind palinuran Polycheles typhlops. Suspended particulate matter concentration in the water column generally decreased from the shelf and upper-slope down to the deep-slope region along the 3 seasonal samplings. Furthermore, vertical fluxes collected near the bottom at $\sim 1000 \mathrm{~m}$ depth showed a clear seasonal trend. We discuss how differential matter sinking to the benthic ecosystems versus species depth distribution may be the proximal cause of decapod crustacean reproductive seasonality, and how phylogenesis and light intensity should also be taken into account when describing how species are adapted to the transitional depths of the continental margin of the NW Mediterranean Sea.
\end{abstract}

KEY WORDS: Reproductive period - Life histories - Deep-water and deep-sea processes · Mass flux · Decapod crustaceans $\cdot$ Mediterranean Sea

\section{INTRODUCTION}

Marine scientists are increasingly aware that all marine ecosystems are highly interconnected and that processes in coastal and shallow habitats have a major influence on deep-water and deep-sea habitats (Gooday 1988, 2002, Asper et al. 1992, Puig et al. 2001, Smith et al. 2002). However, the current information is unbalanced. Marine coastal and shallow habitats have been widely studied, but deep-sea habitats are among the least studied on earth and, consequently, their ecological dynamics are still poorly understood. Nevertheless, a considerable scientific effort has taken place in the last 2 decades. A number of studies describe the reproductive processes of deep-sea species dwelling at depths below 1000 m (Gage \& Tyler 1991, CamposCreasey et al. 1994, Tyler et al. 1994, Ramirez-Llodra et al. 2002) and how these species develop their life cycles in these extreme habitats (Gage \& Tyler 1991, Levin et al. 1994, Ramirez-Llodra et al. 2000). Curiously, the intermediate depth stratum between 200 and $1000 \mathrm{~m}$ has however been neglected. Comparative studies of megafaunal (i.e. total length over $1 \mathrm{~cm}$ ) species dwelling at these intermediate depths have been mainly addressed in terms of growth, biochemi$\mathrm{cal}$ and physiological adaptation to the midwater realm (Childress et al. 1980, and see review by Childress 1995), and even fewer studies are available regarding the benthic realm (Childress et al. 1990, Company \& Sardà 1998, 2000). These intermediate depths have 
strong physical and biochemical gradients: the pressure increases progressively and a physiological boundary has been established at $1000 \mathrm{~m}$ (Somero et al. 1983); the temperature usually decreases by more than $10^{\circ} \mathrm{C}$, although this decrease is not found in the Mediterranean (Hopkins 1985); the trophic resources decrease dramatically; and the light decreases progressively up to $1000 \mathrm{~m}$ before completely disappearing below this depth (Margalef 1986). In this sense, the biological study of congeneric species dwelling across the upper and middle slope habitats should be highly enlightening and may supply valuable knowledge of the biological characteristics present in deeper waters, since these environments act as a physical and biochemical transitional environment between the shallow $(<200 \mathrm{~m})$ and the deep-sea $(>1000 \mathrm{~m})$ domains, to which life cycles of individual species are adapted.

The realisation that deep-water and deep-sea species quickly respond to different temporal patterns of organic input has significant implications for our understanding of animal community structure and ecosystem dynamics (Levin et al. 1994, Eckelbarger \& Watling 1995, Levin \& Gage 1998, Gooday 2002, Smith et al. 2002). Reproductive cycles and life histories of species living in these habitats may have to be adapted to environmental features occurring far away from them, i.e. at the photic zone. Evidence that the seasonal sinking of phytodetritus triggers reproductive processes in species dwelling below $1000 \mathrm{~m}$ depths has been reported by Tyler et al. (1994) and RamirezLlodra et al. (2002). Few studies are available, however, in terms of geographical area and time-series of data regarding reproductive biology of deep-sea species. The knowledge of the duration of the reproductive processes, i.e. number of months during which females are in reproductive activity, has been considered of great importance in order to understand the species-habitat interaction and evolutionary adaptation to the environment (Eckelbarger \& Watling 1995). Seasonal processes in reproduction have been generally attributed only to shallow water species, while continuous biological processes have been generalised to deep-sea habitats linking this seasonless pattern with the 'theoretically' physical stability of the deepsea environments (Orton 1920, Rokop 1974, 1977, and see review by Gage \& Tyler 1991). Nevertheless, more recent works report that, in fact, quite opposite to the first hypotheses postulated, deep-sea species (dwelling below $1000 \mathrm{~m}$ ) show a large variety of reproductive patterns and both seasonal and non-seasonal processes have been described (Blake 1993, Gage 1994, Tyler et al. 1994). Blake (1993) and Tyler et al. (1993) hypothesised that deep-sea polychaetes and 2 sympatric species of seastar with surface deposit feeder characteristics would be more likely to exhibit season- ality in their reproduction than subsurface deposit feeders. Usually, the information available compares the reproductive periods of deep-sea animals with those of 'shallow' ones, but the designation of shallow is confusing when trying to assign a specific depth. Coastal, shelf and upper or middle slope habitats are highly different, and considering all of these together could lead to errors when trying to establish general patterns of comparison between shallow and deep-sea processes.

Biological processes occur at slower rates in deep waters, and, in particular, the metabolic rates of deeperliving species are much slower than their shallowerliving relatives. Slower rates have been largely linked to the need for adapting to the low food availability at greater depths (Smith 1987, Gage 1991, 1992). However, recent hypotheses have indicated that adaptation to low levels of light in mid-depth environments could account for this decline of biological processes, and in particular for the metabolic rates of midwater animals (Childress 1995). The metabolism of midwater fishes, crustaceans and cephalopods decreases down to $1000 \mathrm{~m}$ depth and below this depth the metabolism ceases to decline (Childress \& Somero 1979, Cowles et al. 1991, Seibel et al. 2000). These authors postulate that light plays an important role not only in the distribution of species but also in the evolutionary processes of these midwater animals. A weaker predator-prey interaction due to the low light intensity at greater depths may account for this decline in metabolic rates.

The main objective of the present study is to compare the reproductive periods of the decapod crustacean community dwelling in transitional environments, from shallow (shelf) habitats to deep-sea (lower-slope) habitats, i.e. between 150 and $1100 \mathrm{~m}$, and to correlate these reproductive processes with the spatial-temporal variability of organic fluxes input to these habitats.

\section{MATERIALS AND METHODS}

Specimens. Decapod crustaceans were sampled monthly from November 1992 to October 1993 using a $6 \mathrm{~m}$ high commercial bottom otter trawl fitted with a $6 \mathrm{~mm}$ mesh cod-end liner. Six additional seasonal sampling cruises were carried out to increase the depth range surveyed, using 2 experimental otter trawl gears, an OTBS-14 trawl (Merrett \& Marshall 1981) and an OTMS trawl (Sardà et al. 1998) (see Company $\&$ Sardà [2000] for further information on cruises and sampling procedures). The overall depth range sampled was between 150 and $1100 \mathrm{~m}$ on the upper and middle continental slope in the NW Mediterranean Sea off Barcelona (Fig. 1). A total of 43000 specimens 
from 15 decapod crustacean species were analysed (for details see Table 1). In order to compare the reproductive periods of the most abundant species distributed on the continental margin of the NW Mediterranean Sea, 4 additional species were used in this comparative approach: Aristeus antennatus, Nephrops norvegicus, Macropipus tuberculatus and Liocarcinus depurator (data obtained from Demestre 1990, Sardà \& Lleonart 1993 and Abelló 1989a,b, respectively). Thus, a total of 19 species, belonging to 11 different families and 6 infraorders, were used in this study (Table 1).

Five stages of gonadal development were established for females, as follows: I: immature; II: resting gonads; III, IV and V: 3 stages of recrudescent gonads, i.e. from the initial stages of gametogenesis up to the stage prior to spawning of eggs (according to Company \& Sardà 1997). The stages were defined according to the relative intensity of the colour and size of the gonads. In order to compare the duration of the annual reproductive periods, monthly percentage of females with recrudescent gonads (Stages III, IV and V) and monthly percentages of ovigerous females were represented in relation to the total female population.

Suspended particulate matter distribution. Hydrographic profiles down to $5 \mathrm{~m}$ above the seabed were

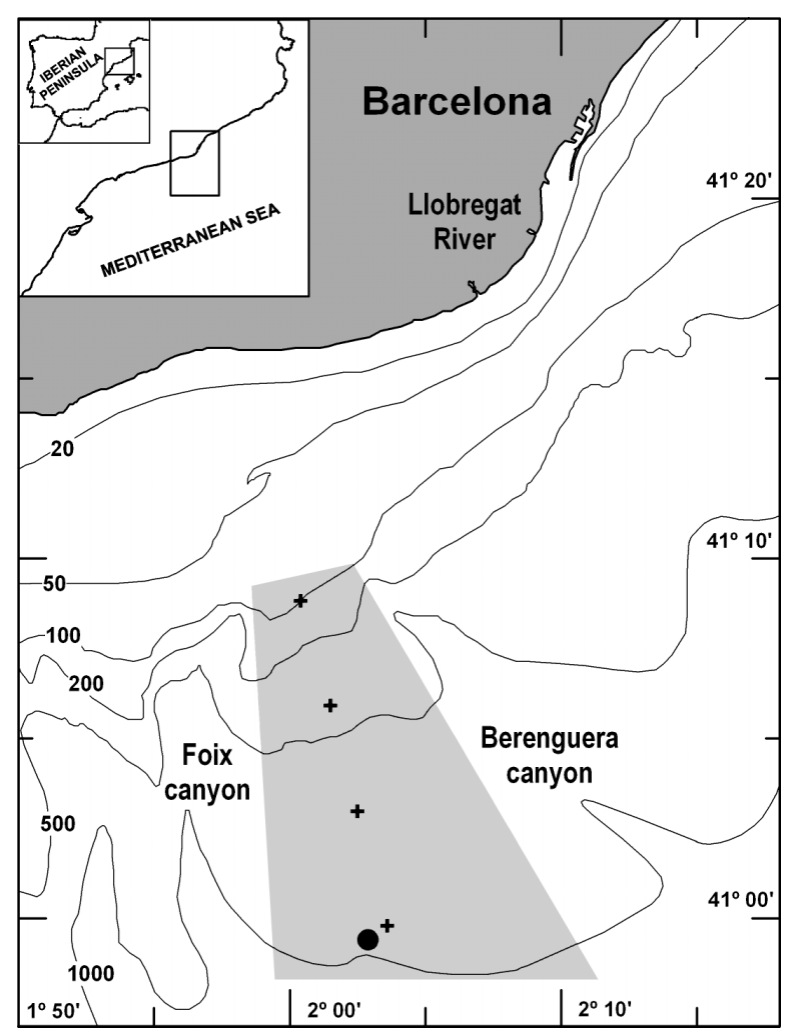

Fig. 1. Bathymetric map of the study area showing the locations of the hydrographic profiles (+), sediment trap (๑) and trawling area (shaded area). Bathymetric contours in $\mathrm{m}$ collected across the continental margin from the shelf down to $1000 \mathrm{~m}$ depth (Fig. 1) using a Neil Brown Mark III CTD coupled with a Sea Tech $25 \mathrm{~cm}$ path length transmissometer. Three oceanographic surveys were carried out in April, June and October 1993 (the April and October surveys were on board the RV 'García del Cid' and the June survey was on board the RV 'Hespérides'). These surveys coincided with the main sampling period of the decapod individuals. The same stations were occupied on all cruises to identify the main hydrographic features and the temporal and spatial variability in particulate matter distribution.

Water samples were collected on each cast near the bottom, at the surface and at intermediate depths by means of 51 Niskin bottles mounted on a General Oceanics CTD rosette sampler. The samples were filtered through pre-weighed Nuclepore polycarbonate filters (diameter $47 \mathrm{~mm}$, pore size $0.4 \mu \mathrm{m}$ ) to determine particulate matter concentration (PMC), and they were used for transmissometer data calibration.

Downward particle fluxes. Annual time-series of downward particle fluxes and organic constituents (biogenic silica and organic carbon) were determined in the same study area during approximately the same period when biological sampling was conducted (Fig. 1). Mass fluxes were obtained fortnightly by means of a sequential sediment trap (PPS3 Technicap) deployed at $980 \mathrm{~m}$ depth, $30 \mathrm{~m}$ above the seafloor, from May 1993 to April 1994. The collected samples were processed in the laboratory according to Heussner et al. (1990). The total samples were divided into several aliquots, to obtain different sub-samples for various analyses. Contaminating zooplankton not related to the passively-sinking flux, also called 'swimmers', were removed by hand, using forceps, under a dissecting microscope.

Sample dry weight was determined using 3 subsamples filtered onto pre-weighed Millipore filters (diameter $47 \mathrm{~mm}$, pore size $0.45 \mu \mathrm{m}$ ), rinsed with distilled water and dried at $40^{\circ} \mathrm{C}$ for $24 \mathrm{~h}$. Total mass flux was calculated from the sample dry weight, the collecting trap area and the time sampling interval.

Biogenic silica (opal) was analysed using a wetalkaline extraction with sodium carbonate according to Mortlock \& Froelich (1989). This analysis consisted of a differential wet-chemical extraction into a $2 \mathrm{M} \mathrm{Na}_{2} \mathrm{CO}_{3}$ solution at $85^{\circ} \mathrm{C}$ for $5 \mathrm{~h}$.

Organic carbon content was measured in duplicate using a Leco induction carbon analyser. Two subsamples were filtered onto pre-weighed Whatman GF/F glass microfiber filters (diameter $47 \mathrm{~mm}$ ), previously combusted at $550^{\circ} \mathrm{C}$ for $24 \mathrm{~h}$. Retained sediment was acidified before the analysis to remove carbonates, by gradually adding a few drops of $\mathrm{HCl}(1 \mathrm{M})$ onto the filter placed in a ceramic sample container, until no effervescence was noticed. 
Table 1. Depth range, depth of maximum abundance, and number of individuals sampled from 19 species of decapod crustaceans in the NW Mediterranean Sea. Mes: mesopelagic; Nek: nektobenthic; Ben: benthic species

\begin{tabular}{|c|c|c|c|c|c|}
\hline Species & $\begin{array}{l}\text { Species } \\
\text { code }\end{array}$ & $\begin{array}{l}\text { Depth } \\
\text { range (m) }\end{array}$ & $\begin{array}{l}\text { Depth of max abundance } \\
(\mathrm{m}) / \text { habitat depth }\end{array}$ & Habit & $\begin{array}{l}\text { No. ind. } \\
\text { measured }\end{array}$ \\
\hline \multicolumn{6}{|l|}{ Suborder Dendrobranchiata } \\
\hline \multicolumn{6}{|l|}{ Infraorder Penaeidea } \\
\hline \multicolumn{6}{|l|}{ Family Aristeidae } \\
\hline Aristeus antennatus ${ }^{\mathrm{a}}$ & $\mathrm{Aa}$ & $176-2261$ & 650/middle slope & Nek & \\
\hline \multicolumn{6}{|l|}{ Family Solenoceridae } \\
\hline Solenocera membranacea & $\mathrm{Sm}$ & $3-871$ & 350/upper slope & Nek-Ben & 6810 \\
\hline \multicolumn{6}{|l|}{ Suborder Pleocyemata } \\
\hline \multicolumn{6}{|l|}{ Infraorder Caridea } \\
\hline \multicolumn{6}{|l|}{ Family Pasiphaeidae } \\
\hline Pasiphaea sivado & Ps & $33-871$ & 350/upper slope & Mes & 4156 \\
\hline Pasiphaea multidentata & Pmu & $128-2261$ & 600/middle slope & Mes & 5491 \\
\hline \multicolumn{6}{|l|}{ Family Processidae } \\
\hline Processa nouveli & Pn & $148-622$ & 250/upper slope & Nek-Ben & 1672 \\
\hline Processa canaliculata & 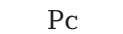 & $70-871$ & 350/upper slope & Nek-Ben & 2617 \\
\hline \multicolumn{6}{|l|}{ Family Pandalidae } \\
\hline Plesionika heterocarpus & $\mathrm{Ph}$ & $82-699$ & 250/shelf-slope & Nek & 2831 \\
\hline Plesionika edwardsii & $\mathrm{Pe}$ & $256-512$ & 350/upper slope & Nek & 1790 \\
\hline Plesionika giglioli & $\mathrm{Pg}$ & $101-748$ & 350/upper slope & Nek & 1601 \\
\hline Plesionika martia & $\mathrm{Pm}$ & $165-871$ & $600 /$ middle slope & Nek & 3877 \\
\hline Plesionika acanthonotus & $\mathrm{Pa}$ & $165-1749$ & 650/middle slope & Nek & 928 \\
\hline \multicolumn{6}{|l|}{ Infraorder Astacidea } \\
\hline \multicolumn{6}{|l|}{ Family Nephropidae } \\
\hline Nephrops norvegicus ${ }^{\mathrm{b}}$ & $\mathrm{Nn}$ & $66-871$ & 450/upper slope & Ben & \\
\hline \multicolumn{6}{|l|}{ Infraorder Palinura } \\
\hline \multicolumn{6}{|l|}{ Family Polychelidae } \\
\hline Polycheles typhlops & $\mathrm{Pt}$ & 267-1949 & 750/middle slope & Ben & 881 \\
\hline \multicolumn{6}{|l|}{ Infraorder Anomura } \\
\hline \multicolumn{6}{|l|}{ Family Galatheidae } \\
\hline Munida intermedia & $\mathrm{Mi}$ & $35-871$ & 400/upper slope & Ben & 672 \\
\hline Munida tenuimana & Mt & $348-1949$ & 650/middle slope & Ben & 1353 \\
\hline \multicolumn{6}{|l|}{ Infraorder Brachyura } \\
\hline \multicolumn{6}{|l|}{ Family Homolidae } \\
\hline Paromola cuvieri & Pcu & $136-1149$ & 500/upper slope & Ben & 41 \\
\hline \multicolumn{6}{|l|}{ Family Geryonidae } \\
\hline Geryon longipes & Gl & $439-1949$ & 650/middle slope & Ben & 522 \\
\hline \multicolumn{6}{|l|}{ Family Portunidae } \\
\hline Liocarcinus depurator ${ }^{\mathrm{C}}$ & $\mathrm{Li}$ & $3-871$ & 150/shelf-slope & Ben & \\
\hline Macropipus tuberculatus ${ }^{\mathrm{d}}$ & Mtu & $48-1149$ & 300/upper slope & Ben & \\
\hline
\end{tabular}

Data presentation. Even though the main sampling periods for both specimens and suspended particulate matter surveys coincided, there was an uncoupling between the capture of the specimens and the annual time-series of downward particle fluxes obtained from the sediment trap. While summer and autumn particle fluxes coincided with specimen collection, winter and early spring particle fluxes were obtained during the $5 \mathrm{mo}$ following, to finish the annual sampling of the specimens. Timing of the main values of downward particle fluxes at $1000 \mathrm{~m}$ depth can vary from year to year depending on the temporal variability of the particle sources (surface planktonic blooms and/or lateral conduits). Although a potential slight uncoupling of our data might be present, it is assumed that on an annual basis the timing at $1000 \mathrm{~m}$ would be similar, thus enabling us to use both sets of data for our comparative study. Both biological and downward particle fluxes data were therefore represented graphically and plotted as a standardised calendar year, i.e. from January to December.

\section{RESULTS}

\section{Duration of reproductive periods versus species depth distribution}

The reproductive periods of 19 decapod crustacean species dwelling across the NW Mediterranean continental margin are shown in Fig. 2 (monthly percent- 

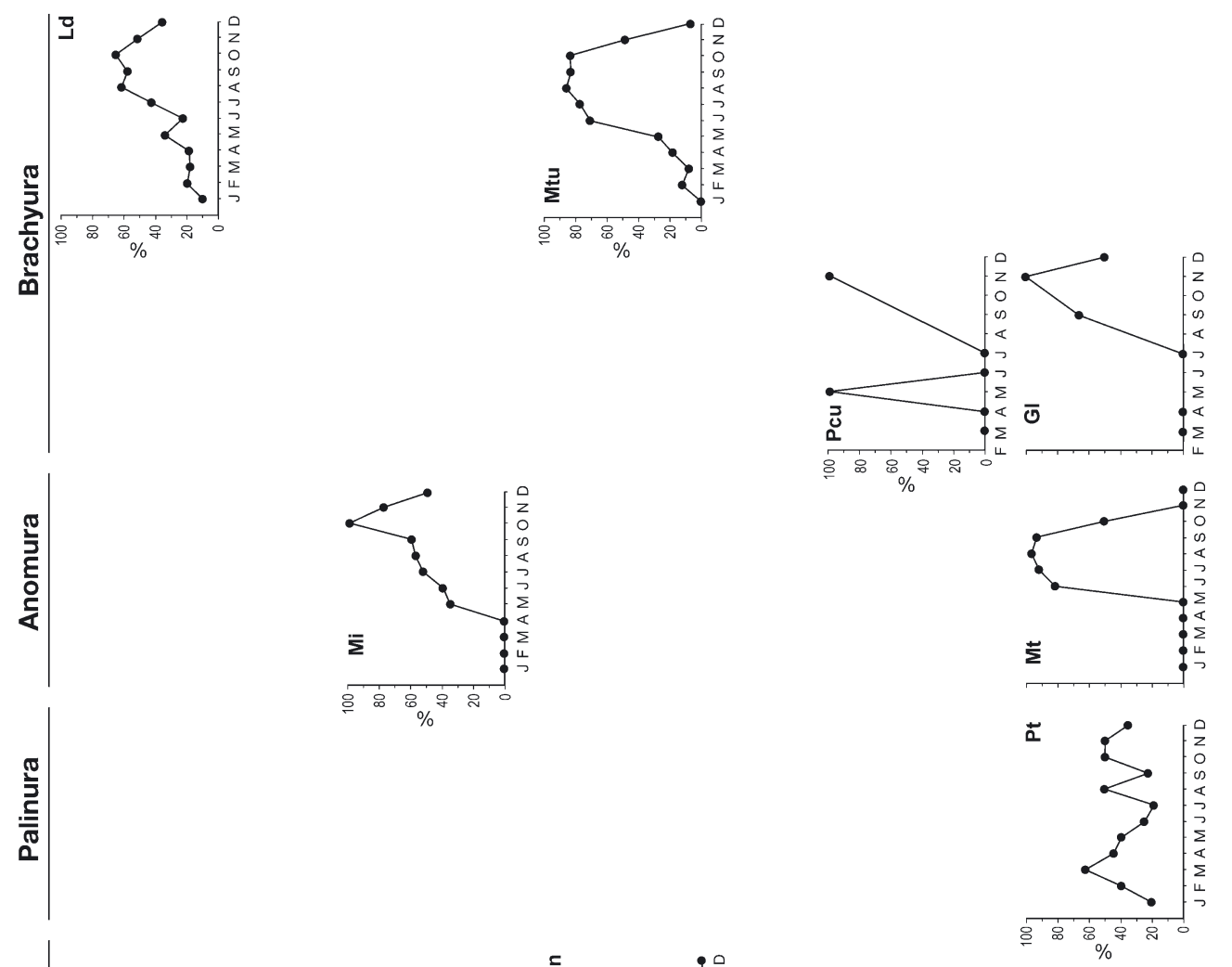

竞
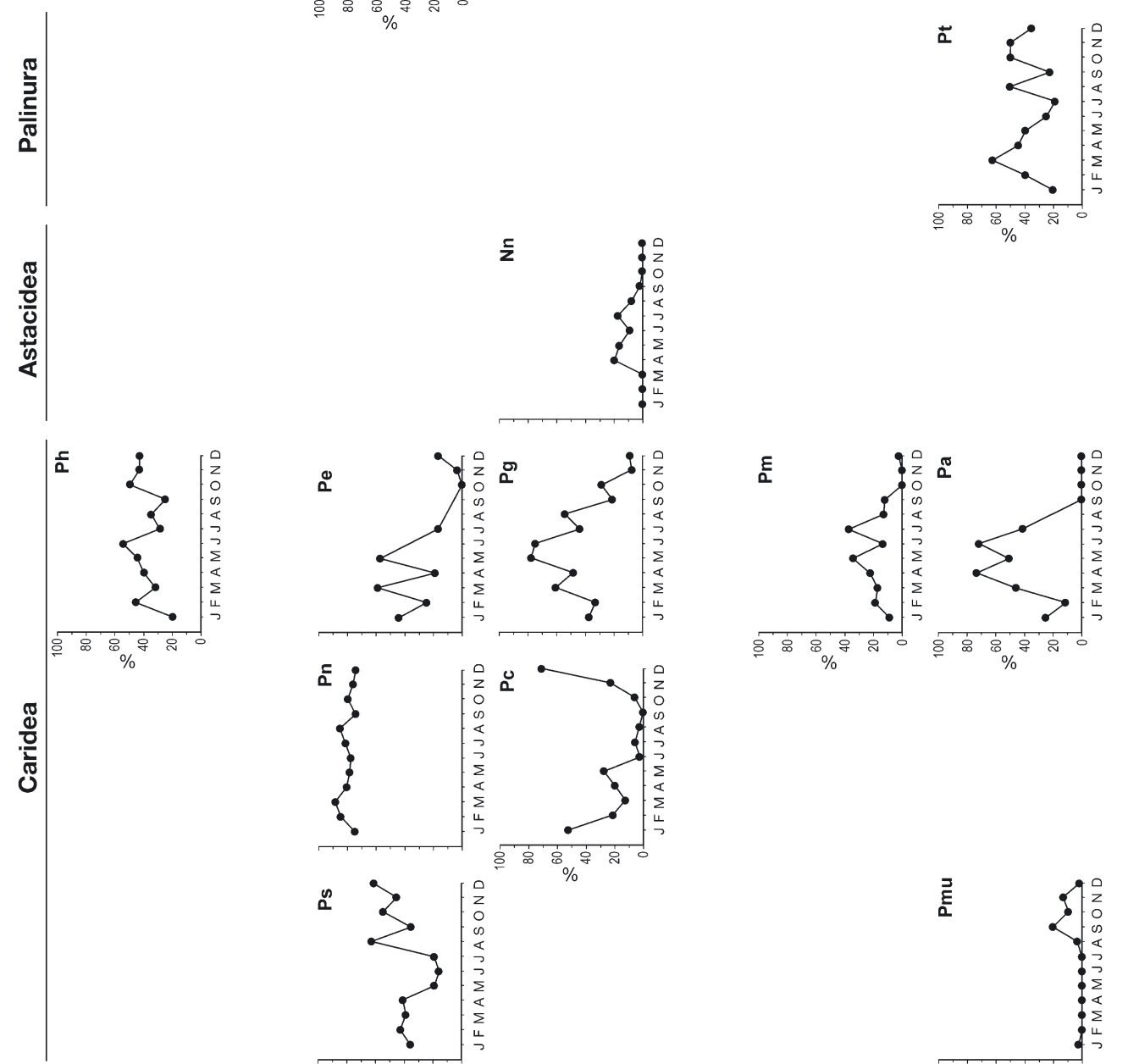

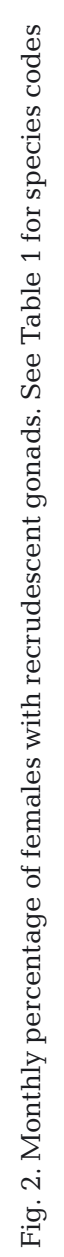
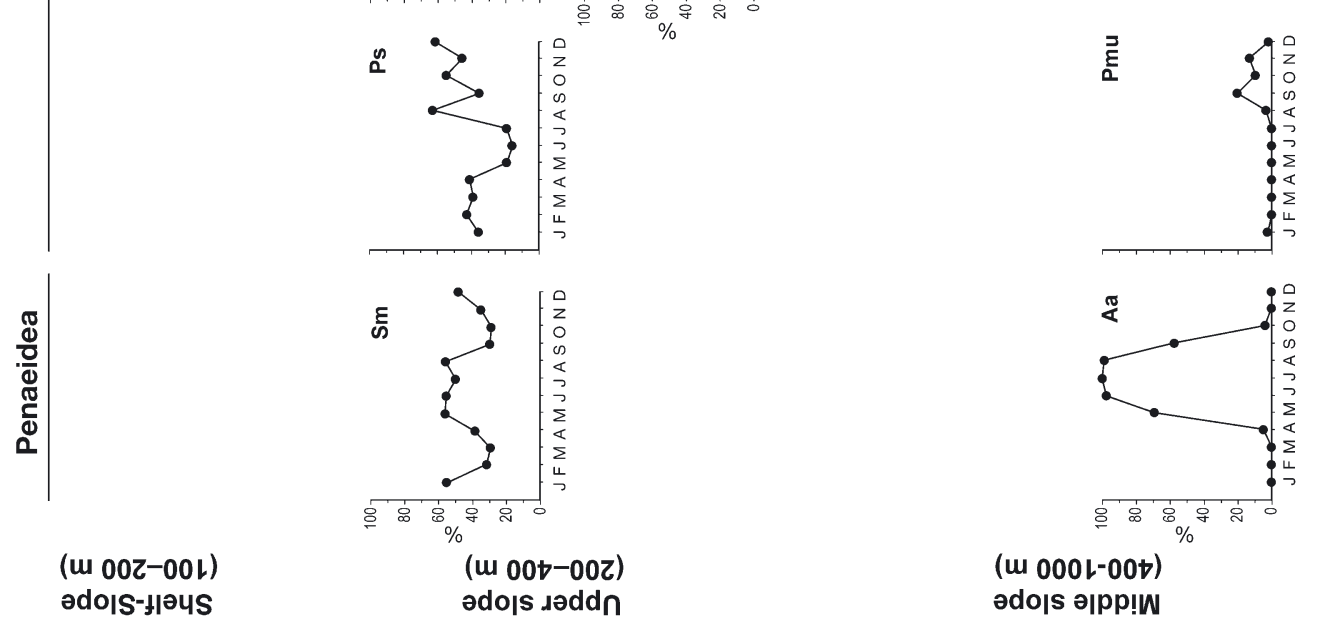

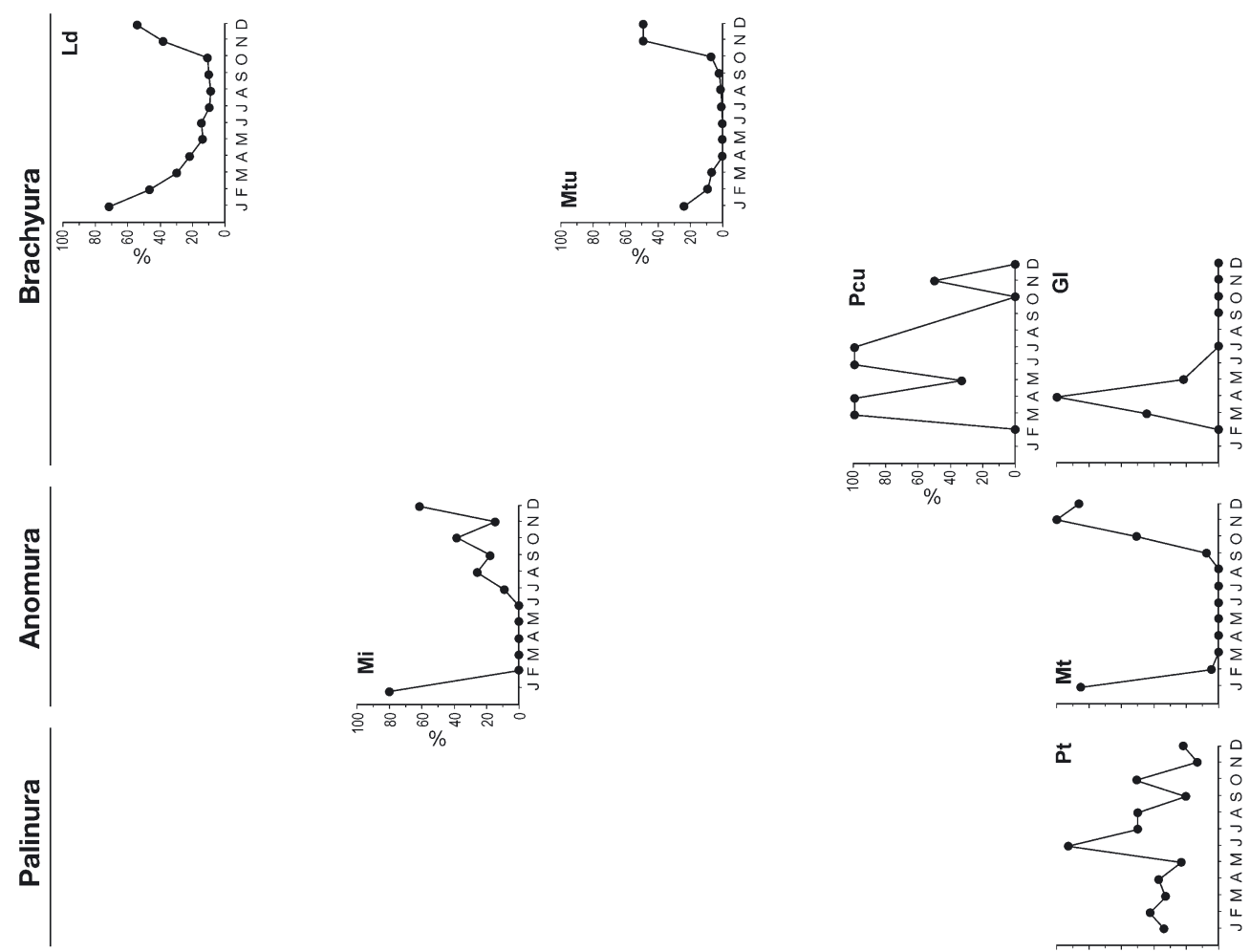

造
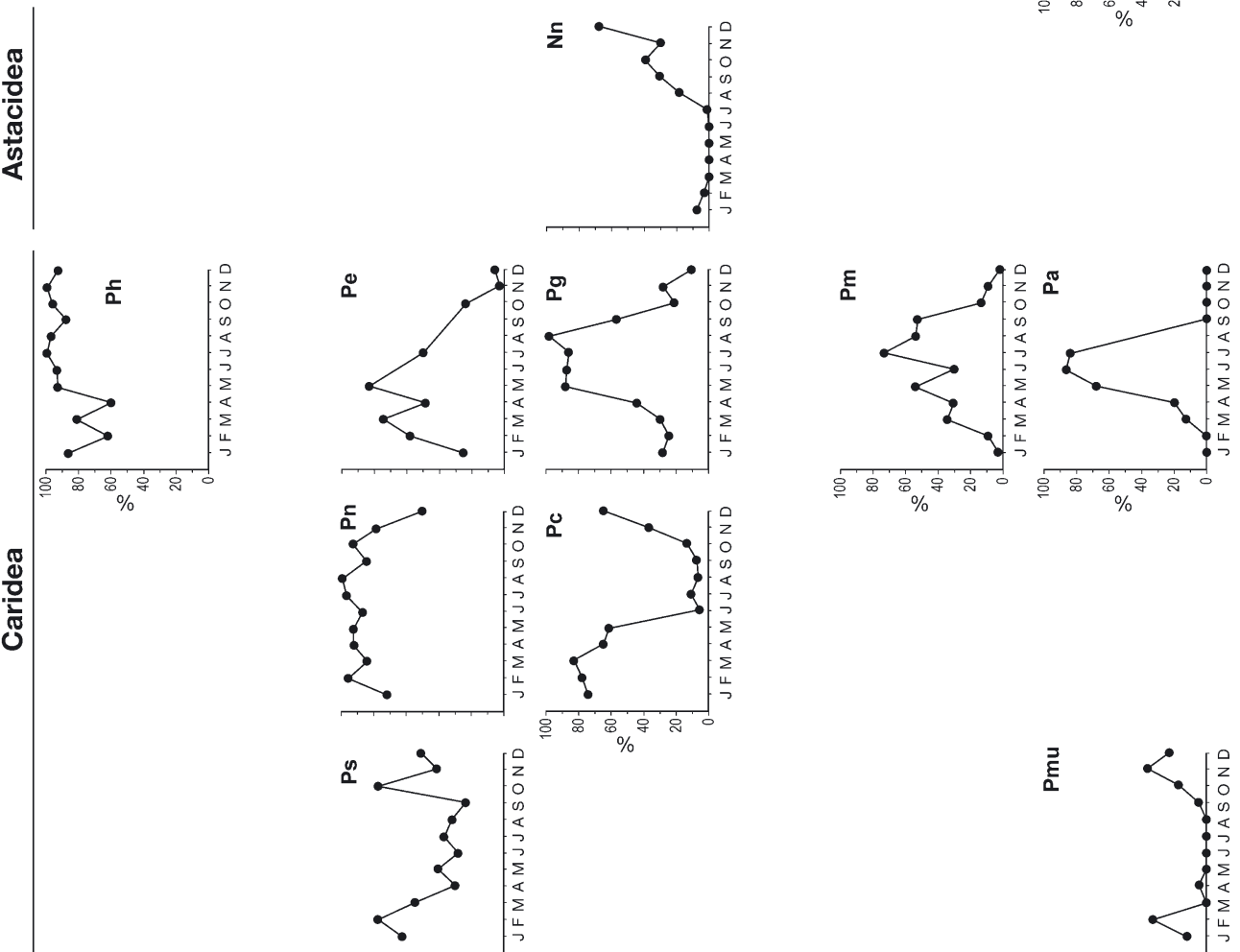

0
0
0
0
0
0
0
0
0
0
0
0
0
0
0
0
0
0
0
0
0
0
0
0
0
0
0
0
0
0
0
0
0
0
0
0
0
0
0
0
0
0
0

\begin{tabular}{|c|}
$\frac{\pi}{0}$ \\
$\frac{0}{0}$ \\
$\mathbb{0}$ \\
$\frac{0}{0}$ \\
0
\end{tabular}
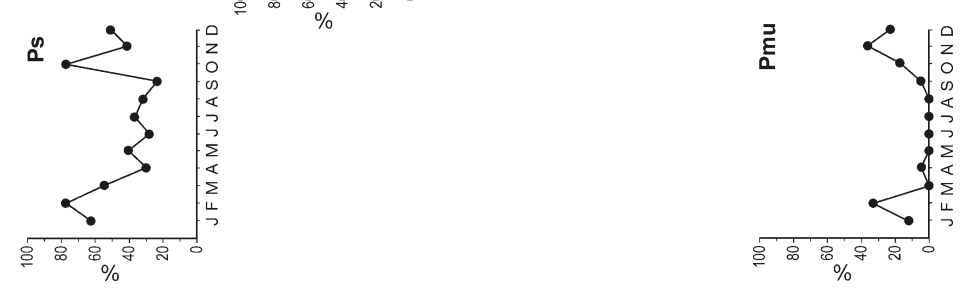
age of females with recrudescent gonads) and Fig. 3 (monthly percentage of ovigerous [berried] females). Congeneric species present maximal reproductive activity in the same season of the year, but species depth distribution affects the period, in months, during which females are reproductively active. Thus, the deepest-dwelling species of each one of the families or genera showed a decrease in the duration of the reproductive periods in comparison with their shallower-living congenerics. This increasing seasonality of the reproductive periods appears in the infraorders, families or genera where more than 2 species were present, i.e. in the 2 Penaeidea species Solenocera membranacea and Aristeus antennatus; in the 2 Pasiphaea spp.; in the 2 Processa spp; in the 5 Plesionika spp.; in the 2 Anomura Munida spp; and finally, in the 2 Brachyura crabs belonging to the family Portunidae, Liocarcinus depurator and Macropipus tuberculatus. For Anomura and Brachyura, the percentage of females with recrudescent gonads was higher in the deepest-dwelling species when compared with the shallow congeneric species of both the anomuran Munida tenuimana and the portunid crab M. tuberculatus. However, the number of months during which the percentage of females with resting gonads was observed was higher in the deepestdwelling species, following the general results described for all the other infraorders. Similar results were obtained for the ovigerous females of these 2 last mentioned infraorders. Finally, the deep-sea brachyuran crab Geryon longipes also had a marked seasonal reproductive period. The reproductive period of this latter species might be compared with the reproductive period of a shallower-dwelling brachyuran crab species, P. cuvieri. Even though very few individuals were available for $P$. cuvieri, females with recrudescent gonads and ovigerous females were found during a higher number of months when compared with $G$. longipes. Thus, species from different genera, families and/or even infraorders, and from different habitats (i.e. epimesopelagic, nektobenthic and benthic-endobenthic shrimps and crabs) show the same biological response in terms of duration of their reproductive periods.

Polycheles typhlops is the only species found below $600 \mathrm{~m}$ depth that did not follow a marked seasonality in its reproductive processes (Figs. $2 \& 3$ ).

\section{Suspended particulate matter distribution and downward particulate matter fluxes}

Suspended particulate matter distribution in the water column of the study area is shown in Fig. 4. In all 3 surveys, suspended particulate matter concen- tration (PMC) showed a general seaward decrease from the shelf and upper-slope down to the deepslope region. Near-bottom particle concentrations in the upper-slope region were at least 2 times higher than those at $\sim 1000 \mathrm{~m}$ water depth. In addition, the upper-slope regions exhibited several intermediate-nepheloid layer detachments, mainly concentrated at the shelf-break (i.e. $120 \mathrm{~m}$ depth) and around 400 to $500 \mathrm{~m}$ depth. These detachments barely reached the deeper study area, where welldeveloped nepheloid layers were not detected below $600 \mathrm{~m}$ water depth and where the PMC was not higher than $0.3 \mathrm{mg} \mathrm{l}^{-1}$.

PMC was similar in the 3 cruises, not showing evident seasonal differences. However, larger sinking particles fluxes collected fortnightly near the bottom at $\sim 1000 \mathrm{~m}$ depth ranged from $108 \mathrm{mg} \mathrm{m}^{-2} \mathrm{~d}^{-1}$ in late September to $1703 \mathrm{mg} \mathrm{m}^{-2} \mathrm{~d}^{-1}$ in late January; they were much higher in winter than in summer and
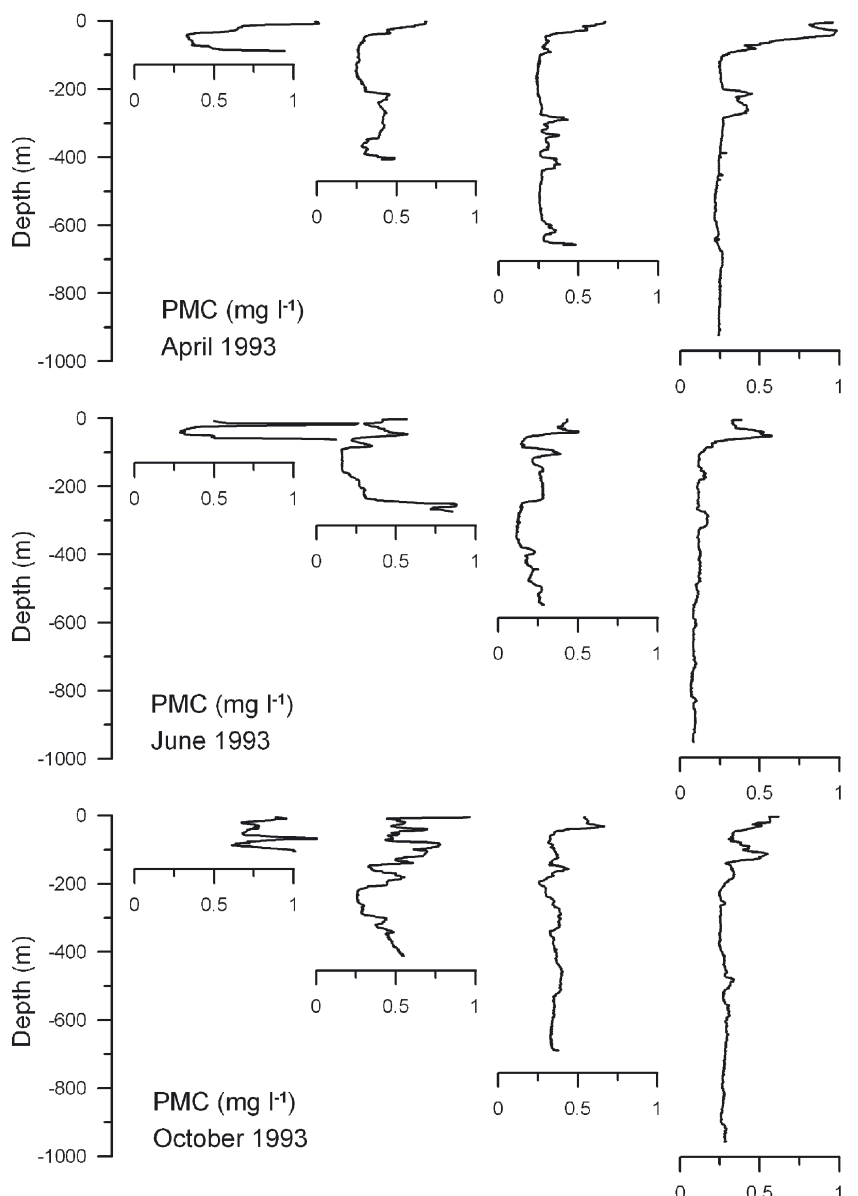

Fig. 4. Particulate matter concentration (PMC) profiles across the studied continental margin during April, June and October 1993. Note the presence of intermediate nepheloid layer detachments in the upper continental slope, but not affecting the deepest profile (below $600 \mathrm{~m}$ ) 

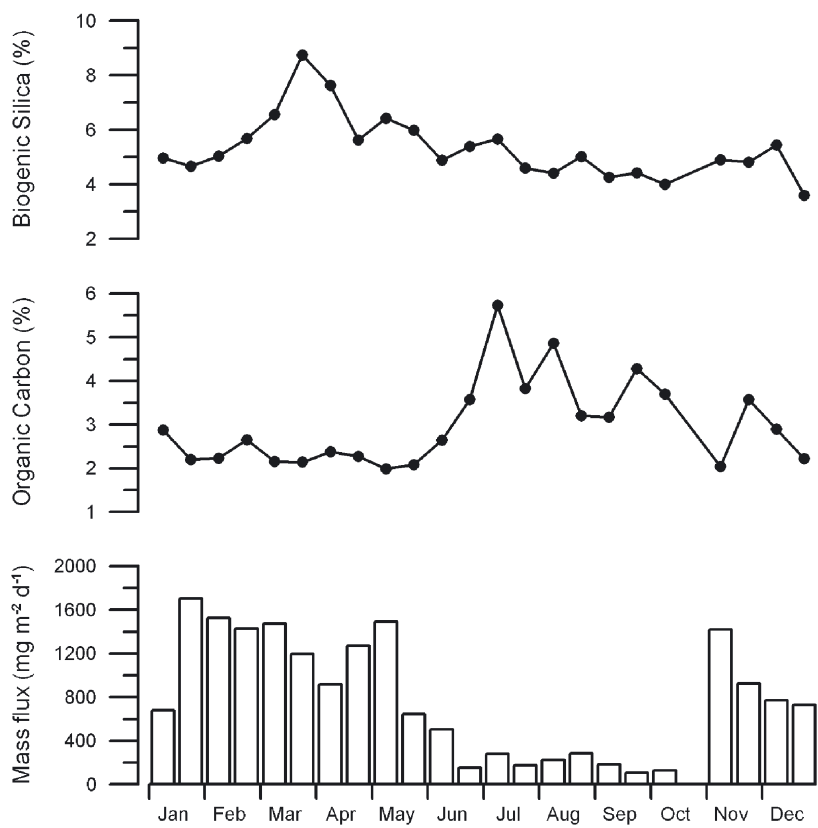

Fig. 5. Annual time course of total mass fluxes, organic carbon and biogenic silica contents of settling particles collected at $\sim 1000 \mathrm{~m}$ depth in the study area

showed a clear seasonal trend (Fig. 5). Organic carbon (OC) content of sinking particles also showed a seasonal variability, which was inversely related to total mass fluxes. During the winter, the OC content was lower and more constant, maintaining values around $2.5 \%$, whereas during the summer the OC content increased and was more variable, reaching a maximum value of $5.7 \%$ in early July. On the other hand, biogenic silica content did not have the same seasonal pattern of the total mass flux and of the organic carbon, but showed a seasonal increase from March to May, associated with the biological spring bloom in surface waters. The lowest values were found during the autumn-winter seasons (Fig. 5).

\section{Timing of reproductive processes}

Fig. 6 compares the timing of the reproductive periods of the species showing seasonal reproductive activity with the near-bottom total mass fluxes and organic composition recorded at $\sim 1000 \mathrm{~m}$. Thus, in this figure, all the deepestdwelling species available were represented with the sole exception of Polycheles typhlops, i.e. the single middle-slope dwelling species that did not present a marked seasonal reproductive period. The reproductive periods of the species shown in Fig. 6 have not been ordered phylogenetically (as in Table 1) nor by life habits (i.e. from pelagic to endobenthic or from endobenthic to pelagic). Rather, the species have been ordered from top to bottom according to the month in which females with recrudescent gonads started to appear.

Middle-slope dwelling species undergo their maximal reproductive activity at different seasons of the year, and a direct correlation between both the timing of the mass fluxes and the timing of the reproductive periods could

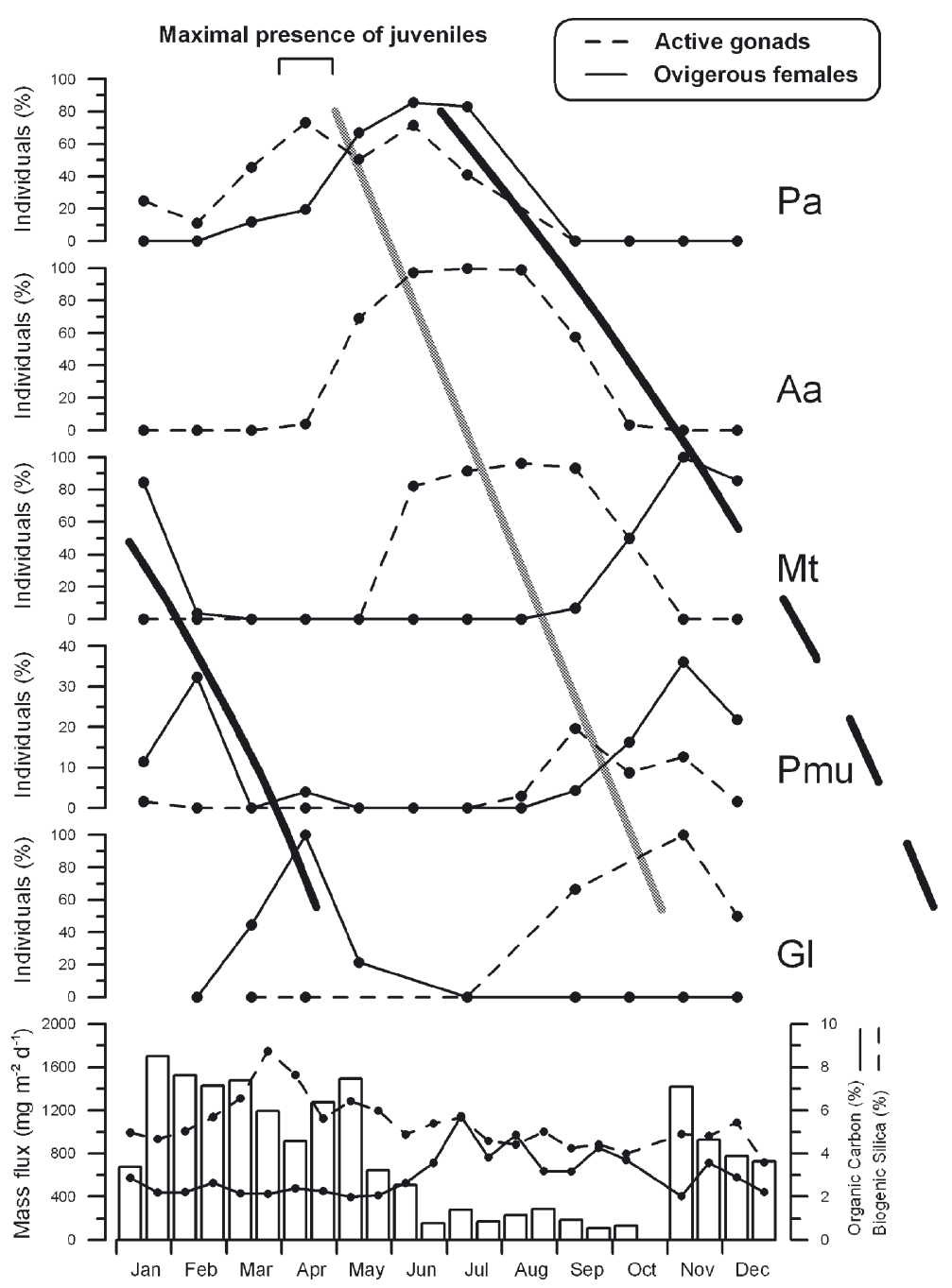

Fig. 6. Relationship between specific season of maximal reproductive activity for the seasonally reproductive species and the particulate matter sinking. Species have been ordered from top to bottom. Thick grey line: joins the month of maximal percentage of females with recrudescent gonads in each species; thick black line: joins the month of maximal percentage of ovigerous females in each species; dashed thick black line: assumed prolongation of maximal percentage of ovigerous females to the following year. See Table 1 for species code 
not be determined (Fig. 6). However, females of all these species start to have recrudescent gonads, or present their reproductive periods, in the spring and summer months, immediately after the spring bloom (maximal percentage of biogenic silica) and after the abrupt decrease of the total matter sinking to the bottom. Looking at the relationship between the reproductive periods of every species and the mass fluxes, the data show how minimal mass flux and the maximal organic input to the sea bottom coincide with the species that mainly reproduce during spring and summer months (i.e. Aristeus antennatus, Plesionika acanthonotus and the activation of the female gonads of the anomuran species Munida tenuimana). Total maximal fluxes are related to species that reproduce during the autumn and winter season (i.e. Pasiphaea multidentata, and ovigerous females of M. tenuimana and Geryon longipes).

When the reproductive periods of the seasonal species are ordered, an unexpectedly perfect asynchronism between species appears. In Fig. 6, it can be seen how females of $P$. acanthonotus with recrudescent gonads (thick grey line) start to be present during January (although maximal percentages were in March-April) and females with recrudescent gonads of other species progressively appeared in the later months. The same trend was observed for the presence of ovigerous females (thick black line).

\section{Biological traits related to the timing of the reproductive processes}

Some biological characteristics of the deepestdwelling species studied here are indicated in Table 2 with the aim of finding biological features that may correlate with both the timing of the reproductive periods and the timing of the first appearance of juveniles in the habitat. The data in Table 2 has been derived from several sources (see footnotes, Table 2). The fact that species dwelling in the shallowest range studied here presented a continuous reproductive activity (which means no clear seasonality of juvenile appearance; see Company \& Sardà 2001 for example of species of the genera Pasiphaea), made it impossible to present this relationship for all the species studied here. Polycheles typhlops has been included in this comparison in order to point out the biological differences from the other species shown in Table 2. In order to make the results in Table 2 more comprehensible, some general characteristics of decapod crustacean biology need to be mentioned. The time-lapse between larval release and larval settlement is highly correlated with egg size and larval size at hatching, which is a phyletic trait relatively similar within family taxa, when compared among different families of animal invertebrates (Giangrande et al. 1994, Eckel-

Table 2. Relationship between reproductive periods, first appearance of juveniles and egg size/number/colour among decapod crustaceans dwelling in the deepest bathymetric range sampled in this study (between 600 and $1100 \mathrm{~m}$ depth). Species are ordered, from left to right, following the phylogenetic classification shown in Table 1, except for Polycheles typhlops, which is the only 'non-seasonal' reproductive species of this table. nd: no data available

\begin{tabular}{|c|c|c|c|c|c|c|}
\hline \multirow{2}{*}{$\begin{array}{l}\text { Biological } \\
\text { characteristics }^{a}\end{array}$} & \multicolumn{6}{|c|}{ Species } \\
\hline & $\begin{array}{l}\text { Aristeus } \\
\text { antennatus }\end{array}$ & $\begin{array}{l}\text { Pasiphaea } \\
\text { multidentata }\end{array}$ & $\begin{array}{l}\text { Plesionika } \\
\text { acanthonotus }\end{array}$ & $\begin{array}{l}\text { Munida } \\
\text { tenuimana }\end{array}$ & $\begin{array}{l}\text { Geryon } \\
\text { longipes }\end{array}$ & $\begin{array}{l}\text { Polycheles } \\
\text { typhlops }\end{array}$ \\
\hline First appearance of juveniles & $\begin{array}{l}\text { Autumn } \\
\text { (December) }^{\mathrm{a}}\end{array}$ & $\begin{array}{l}\text { Winter } \\
\text { (March) }^{\mathrm{b}}\end{array}$ & nd & nd & nd & nd \\
\hline Main presence of juveniles & $\begin{array}{l}\text { Winter } \\
\text { (March) })^{a, c}\end{array}$ & $\begin{array}{l}\text { Early spring } \\
{\text { (April) })^{\mathrm{b}}}\end{array}$ & $\begin{array}{l}\text { Early spring } \\
\text { (April) }^{\mathrm{d}}\end{array}$ & $\begin{array}{l}\text { Spring } \\
\text { (May) }^{\mathrm{e}}\end{array}$ & nd & Year round ${ }^{\mathrm{e}}$ \\
\hline $\begin{array}{l}\text { Maximal \% of females with } \\
\text { recrudescent gonads }\end{array}$ & Summer ${ }^{c, f}$ & Autumn $^{\mathrm{f}}$ & $\begin{array}{l}\text { Spring- } \\
\text { Summer }\end{array}$ & $\begin{array}{l}\text { Summer- } \\
\text { Autumn }^{f}\end{array}$ & $\begin{array}{l}\text { Summer- } \\
\text { Autumn }\end{array}$ & Year round ${ }^{\mathrm{f}}$ \\
\hline Maximal \% of ovigerous females & g & Autumn-Winter ${ }^{\mathrm{f}}$ & Summer ${ }^{\mathrm{f}}$ & Autumn-Winter ${ }^{\mathrm{f}}$ & Winter-Spring $^{\mathrm{f}}$ & Year round ${ }^{\mathrm{f}}$ \\
\hline $\begin{array}{l}\text { Time lapse (in months) between } \\
\text { maximal \% of females with re- } \\
\text { crudescent gonads and maximal } \\
\text { presence of ovigerous females }\end{array}$ & $\begin{array}{l}0 \\
\text { (this is a } \\
\text { free spawning }_{\text {species) }^{\mathrm{f}}}\end{array}$ & $1-2^{f}$ & $2-3^{\mathrm{f}}$ & $3-4^{\mathrm{f}}$ & $4-5^{f}$ & $\begin{array}{l}\text { Continuous } \\
\text { reproductive } \\
\text { period }^{\mathrm{f}}\end{array}$ \\
\hline Egg size $\mathrm{s}^{\mathrm{h}}$ & $(\text { Small })^{\mathrm{i}}$ & $\mathrm{Big}^{\mathrm{b}}$ & Medium $^{\mathrm{j}}$ & $\mathrm{Big}^{\mathrm{e}}$ & Medium $^{\mathrm{e}}$ & Medium $^{\mathrm{e}}$ \\
\hline Egg number ${ }^{\mathrm{h}}$ & $(\mathrm{Big})^{\mathrm{i}}$ & Small $^{\mathrm{b}}$ & Medium $^{\mathrm{j}}$ & Small ${ }^{\mathrm{e}}$ & Big $^{\mathrm{e}}$ & Medium $^{\mathrm{e}}$ \\
\hline Exoskeleton colour & Violet $^{\mathrm{e}}$ & Translucid-violet $^{\mathrm{e}}$ & Violet $^{\mathrm{e}}$ & Red-violet $^{\mathrm{e}}$ & Violet $^{\mathrm{e}}$ & White-red ${ }^{\mathrm{e}}$ \\
\hline Egg colour & $(\text { Violet })^{\mathrm{e}}$ & Translucid-violet ${ }^{\mathrm{e}}$ & Violet $^{\mathrm{e}}$ & Violet $^{\mathrm{e}}$ & Violet $^{\mathrm{e}}$ & White \\
\hline
\end{tabular}


barger \& Watling 1995, Giangrande 1997). Also, timing of larval settlement must be somehow correlated with the timing of the species' reproductive periods. On the other hand, it has been demonstrated that matter sinking to the bottom is positively correlated with meioand macrofauna abundance and distribution in deepwater and deep-sea habitats (Levin \& Gage 1998, Smith et al. 2002 and references therein). No clear information is available at present regarding the relationship between megafaunal biomass fluctuations and spatial distribution versus differential matter fluxes to the benthic system. Thus, megafaunal biological processes may not be directly related to energy input to the bottom, mainly due to their higher level in the trophic chain. However, megafaunal reproductive processes could be highly related, or adapted, to energy input and the processes occurring in the photic zone due to larval processes (dispersion/ survival/settlement). Thus, Table 2 shows how the maximal presence of juveniles of several species was detected from late winter to early spring, even in species that present different timing of their reproductive periods (Fig. 6). The 'autumn-winter' reproductive species e.g. Pasiphaea multidentata and Munida tenuimana, present a relatively low egg number and a relatively big egg size, which is directly related to a spring maximal presence of juveniles (short pelagic larval life). Spring and summer reproductive species, e.g. Aristeus antennatus and Plesionika acanthonotus, show a free spawning and a relatively intermediate egg size and egg number, respectively, which is related to longer pelagic life of the larvae. On the other hand, if the reproductive periods of the species represented in Fig. 6 had been ordered phylogenetically, i.e. from Penaeidea to Brachyura (see Table 1 for the phylogenetic order of the species), it would have been possible to see graphically how a longer period of time between maximal presence of females with active gonad and maximal presence of ovigerous females applied to species that have a higher position in the phylogenetic classification. Thus, in Aristeus antennatus there was no time-lapse between maximal presence of females with recrudescent gonads and ovigerous females, because this species does not carry eggs in the abdomen; in P. multidentata this time lapse is only 1 to $2 \mathrm{mo}$; in comparison to the Brachyura crab Geryon longipes, where the time lapse was 4 to 5 mo (see specific details in Table 2). This latter aspect is a phyletic trait, associated with the time spent for both the gametogenesis and the incubation of the eggs in their abdomens before hatching.

Polycheles typhlops is the only species dwelling at the deepest range of this study that did not follow any of the general trends described until now. As mentioned, it is reproductively active all year round (Figs. 2
\& 3). Moreover, this species has no distinguishable seasonal recruitment of its juveniles; the exoskeleton colour is different from that of the other middle-slope dwelling species; and while violet is the common colour of female gonads and eggs for all these species, P. typhlops has eggs of a milk-like colour (Table 2).

\section{DISCUSSION}

\section{Increasing seasonality of the reproductive periods with increasing species depth distribution}

Tyler (1988) and Gage \& Tyler (1991) postulated that, if a seasonal reproductive process is present in deepsea species, an environmental feature should play a role. However, information available concerning any such links is very scarce (Campos-Creasy et al. 1994, Ramirez-Llodra et al. 2002). While studying the interspecific reproductive variability, 2 factors must be taken into consideration: the endogenous control, i.e. the endocrinic control of the gametogenetic process, and the exogenous influence, i.e. the environmental control throughout the entire reproductive process (Giangrande et al. 1994, Eckelbarger \& Watling 1995, Giangrande 1997). Currently, data on deep-sea invertebrate reproductive aspects is mainly available for actinians, peracarid crustaceans, brachiopods, bivalves and echinoderms (Harrison 1988, Tyler 1988, Bishop \& Shalla 1994, Campos-Creasy et al. 1994, Ramirez Llodra et al. 2000, Sumida et al. 2000, Cartes et al. 2001), indicating that both seasonal and continuous reproductive patterns are adopted by deep-sea species, even when they coexist in the same area, but continuous reproduction is still the most common in deep-sea habitats below $1000 \mathrm{~m}$ (Tyler et al. 1994). Decapod crustaceans usually do not figure in these comparative review works; however, this taxon is one of the best represented in subtropical waters, such as the Mediterranean Sea (Sardà et al. 1994, Maynou \& Cartes 2000, Abelló et al. 2002). Decapod crustaceans display a large variety of habits and life strategies (Company \& Sardà 1998, 2000) along the Mediterranean continental margins, being the largest invertebrate megafaunal group (Sardà et al. 1994).

The present study focused on the transitional depth between shallow and deep-sea environment (below $1000 \mathrm{~m}$ depth, Rowe 1983). In some cases, several species of a single genus (e.g. Pasiphaea, Processa, Plesionika and Munida) occupied the entire depth range studied, and there appears to be an adaptive divergence of the traits of the reproductive periods of closely related species as a function of their habitat depth. Conversely, there is strong evidence of the convergence of properties of species with different life 
habits and/or different genera, families and even infraorders. Coastal and shelf dwelling species present highly variable reproductive traits in terms of seasonality, with many species reproducing throughout the year and many others being distinctly seasonal (Giangrande et al. 1994). The same variability of reproductive period duration has been described for deep-sea species dwelling below $1000 \mathrm{~m}$ depth (Blake 1993, Tyler et al. 1994). It therefore would appear that the variability within the 2 separate environments may be linked to a larger variety of factors. Seasonality, or lack of it, in both shallow and deep-sea waters can be linked directly to phylogenetic constraints and/or opportunism/adaptation to specific habitat characteristics, for example rocky habitats in shallow depths or hydrothermal vents in deep-sea waters (see Ramirez Llodra et al. 2000 for details on reproductive traits of 3 hydrothermal vent caridean shrimps). But, for the intermediate depths studied here, environmental factors seem to play a proximate role in the duration of these reproductive periods.

The decrease in organic matter input at increasing depths and the seasonality of these inputs are considered directly linked to the biological activity of the deep-sea habitats (Gage 1994, Levin et al. 1994, Smith et al. 2002). The present data suggest that the observed progressive decrease in the duration of the reproductive periods is related to this decrease of matter input (see Fig. 4), preventing females from allocating energy to their reproductive processes throughout the year. Although information on temporal variability of downward fluxes in the study area is only available at $\sim 1000 \mathrm{~m}$ water depth, some insights can be obtained from the hydrographic profiles recorded across the continental margin in April, June and October 1993. PMC profiles reflected a similar distribution of suspended particles throughout the year (Fig. 4). The fact that nepheloid layer detachments are always preferentially developed in the upper-slope region suggests that this part of the margin can receive a more continuous supply of particulate matter from resuspension processes and lateral transport than the deeper regions, where intermediate nepheloid structures are not developed (Puig \& Palanques 1998a). These permanently high concentrations of suspended particles at shelf/slope break and upper-slope have been related to life-histories, population structure and recruitment processes of some decapod crustaceans species (Puig et al. 2001). Furthermore, this supply of suspended particles through intermediate nepheloid layer detachments is more continuous and diminishes the importance of the vertical fluxes coming directly from surface waters in the upper continental slope region, where, therefore, the input of matter to the benthic organisms is less seasonal than in deeper waters. On the other hand, downward particle fluxes at $\sim 1000 \mathrm{~m}$ are less affected by lateral inputs of matter and they exhibit a clear seasonal trend (Fig. 5). This strong seasonal variability in total mass fluxes in the middle-slope region is related to a low sediment transfer during the summer season, which is associated with sea water stratification, absence of storm resuspension events and river avenue events, lower mesoscale activity of the along-slope geostrophic current and the reduction in the biological activity in surface waters due to the restriction on the diffusion of nutrients from deep layers to the photic zone (Puig \& Palanques 1998b).

Before attempting to find a general pattern in reproductive processes of the upper- and middle-slope dwelling species, it is important to point out that fish, as the other main megafaunal taxa component of these depths in the Mediterranean Sea, and other invertebrates besides decapod crustaceans should be accounted for. Unfortunately, the data for these other taxa are scarce in the Mediterranean (usually no yearround available and not simultaneously obtained with environmental data). Eckelbarger \& Watling (1995) concluded that reproductive biology of deep-sea invertebrates should first consider the phyletic history of individual species before attempting to explain observed reproductive patterns. They therefore suggest that generalisations regarding the reproductive response of any diverse assemblage of deep-sea organisms to organic input are inherently simplistic, if these assume that all species within the group possess the same capacity to respond to this stimulus. However, the evidence reported here is strong enough for us to present a first hypothesis, represented graphically in Fig. 7, in which an 'energy availability' control may first be suggested, i.e. that a decrease in the available energy does not allow a year-round reproduction activity for the middle-slope dwelling species. Species living in these intermediate depths (150 to $1000 \mathrm{~m}$ ) present a progressive decrease of the duration of their reproductive processes and the observed trend is unlikely to be due to phylogenetic constraints. All the species of this study, except for Polycheles thyphlops, have visual-feeder habits throughout their life cycle, as adults (Cartes 1998) and, presumably, in the larval stage, although no information about trophic habits exists for the larval stages of the majority of these species (Rotllant et al. 2001).

However, this first attempt to describe a general response to the surrounding environmental features does not take into account the species of the infraorder Palinura, Polycheles typhlops, which showed continuous reproductive activity year round.

The year-round constant temperature (Hopkins 1985) found in the Mediterranean between 150 and $~ 5000 \mathrm{~m}$ (the deepest part of the Mediterranean) could also be an 


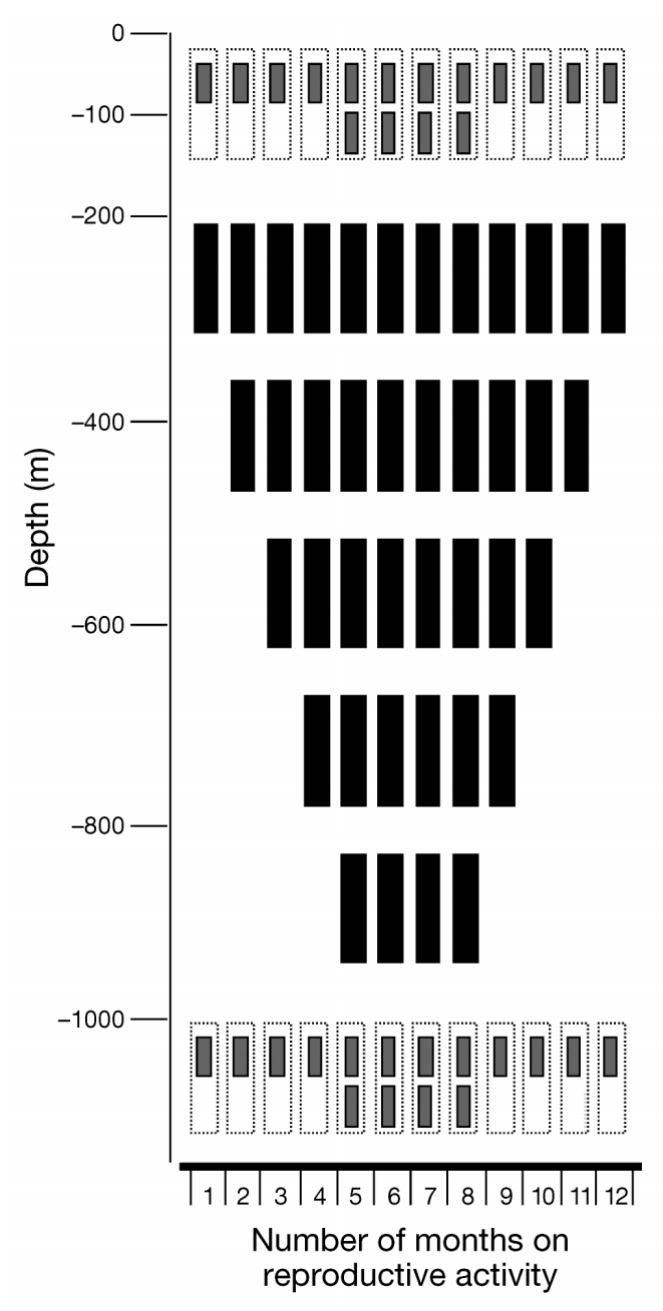

Fig. 7. Scheme of the relationship between duration of reproductive periods and depth of distribution of visual-feeder megafauna dwelling across the continental margins of the NW Mediterranean Sea. Black bars: hypothesised number of months in which species may undertake their reproductive activity supported by the data presented in this study; grey bars: hypothesised co-occurrence of seasonal and continuous reproductive species at shelf and lower-slope depths

environmental aspect to consider for this generalised behaviour. However, variability of the surface temperature plays an important role on the oceanographic processes, physically and biochemical, in the photic zone. Thus, vertical flux to the seabed and some stages of the life cycles of the deep-water species must be directly affected by the seasonal temperature changes.

\section{Timing of reproductive processes of deep-water Mediterranean decapod crustaceans}

The interpretation of the differential timing of the reproductive periods, i.e. the specific season of the year of these processes, seems less clear. There are many gaps in information and any general conclusion will certainly be inaccurate due to the shortage of knowledge about definite biochemical cues triggering the reproductive processes in deep-dwelling species. When looking at the data presented in Figs. 2, $3 \& 6$ and Table 2, other aspects apart from those considered in the above discussion section surely should be taken into account. If reduced energy availability affects the duration of the reproductive period, why does this not equally affect the timing of these reproductive periods? In other words, if the matter fluxes are highly seasonal and if, at certain seasons of the year, this energy input is not sufficient to trigger biological processes in deeper waters, why do all the species not synchronise their periods in the same season? Thus, the uncoupling found between matter fluxes and reproductive processes of the species showing seasonal reproductive activity studied here suggests that differential seasonal availability of energy does not affect all species reproductive processes equally. In shallow water dwelling species, it is just beginning to be understood how gametogenesis, spawning, larval release and larval settlement processes are controlled by many different hormonal and environmental factors, and how the different taxa or species respond very differently under the same environmental features (Rodríguez et al. 1993, see reviews of Giangrande et al. 1994 and Giangrande 1997 on life-histories of marine invertebrates and specifically for polychaetes, one of the best known marine invertebrate groups in terms of biological response against environmental features). These biochemical cues and control pathways are one of the least understood biological aspects of deep-water ecological dynamics. In the study area, besides the depth reduction of particulate matter concentration, we found a highly seasonal trend of downward fluxes at $1000 \mathrm{~m}$ depth, both in terms of quality and quantity of particulate matter that reached the deep-slope region. As shown in Fig. 5, OC content is higher from June to November, whereas during the rest of the year it is almost constant $(\sim 2.5 \%)$. These high OC\% values are clearly associated with the lower total mass fluxes recorded in summer, which leads to a smaller supply of lithogenic particles from the shelf and to the consequent enrichment of organic matter in the settling matter. Biogenic silica is another organic constituent of the particle flux that shows a seasonal trend. Maximum opal percentages are recorded during March-April, related to the biological 'spring bloom' in surface waters and to the consequent higher sedimentation rate of siliceous skeleton organisms. However, our data do not allow any correlation of the timing of the reproductive periods with any specific type of the matter fluxes described here. In spite of this, it is assumed that the variability, in terms of quan- 
tity and quality of the fluxes, should have a direct or indirect effect on the differential timing of the reproductive processes of the deep-dwelling species studied here, but some other biological aspects could also be appealing. Much research still needs to be done in order to understand the biochemical and environmental cues that affect the reproductive periods of each individual species.

Even with the lack of information mentioned above, phylogenetic traits must be taken into account while describing the differential timing of the reproductive processes of the species dwelling on the Mediterranean middle-slopes in the sense that each individual species responds differentially to the surrounding environmental features described here, which contradicts the postulated environmental control on the duration of the reproductive periods mentioned above. Phylogenetic constraints are present at family level, among other taxonomic levels, influencing the egg size, egg number by cohort (Giangrande et al. 1994, Eckelbarger \& Watling 1995) and, from the data presented here, these phylogenetic traits also influence the main reproductive season. Thus, our results show that seasonal organic fluxes to the deep-water floor provoke a variety of reproductive responses in unrelated taxa, i.e. phylogenetically diverse species presented a differential timing of their reproductive processes, but all respond equally in terms of the duration of these processes, suggesting that the proximate cause controlling the duration of the reproductive periods of the Mediterranean middle-slope decapod crustaceans is the decrease in energy input to the benthic system and the ultimate cause is the phylogenetic traits. The phyletic traits of each genus, such as egg size and larval size, must be determinant in the adaptive processes of the species to the environmental features of a specific region. As discussed by Company et al. (2001), the species of a highly cosmopolitan genus such as Pasiphaea undergo reproductive activity at different seasons of the year in each different ocean where they are distributed, but all these species present a relatively large egg size in comparison with other decapod genera, an aspect that will impart an invariable selective pressure while colonising new habitats. Each species possesses a unique suite of lifehistory characteristics, gathered over a long evolutionary history, and that imparts selective advantages (or disadvantages) under a given set of environmental conditions (Eckelbarger \& Watling 1995).

Finally, the unexpected finding regarding the quasiperfect timing asynchrony of the reproductive periods of the deepest-dwelling species studied in this work (see Fig. 6) adds a third aspect when describing the reproductive processes of the decapod crustacean of the NW Mediterranean Sea. To our knowledge, no information related to this latter aspect is available for deep-water invertebrates. It appears that in addition to environmental control on the duration of the reproductive processes, and the phylogenetic traits related to the timing of these processes, an extra biological trait might be suggested while describing how species are adapted to their habitats: inter-specific competition for available resources on a space/time scale. This last feature of the biology of the decapod crustacean of the Mediterranean middle-slopes represents a singular case study of a perfect adaptation and linkage of species to the environmental features of their surroundings, maximising the benefit from stored female energy as the larvae is released in the most favourable season for their survival. This inter-specific timing asynchrony of the reproductive processes needs further and deeper research due to its implications for our understanding of benthic community structure and dynamics.

\section{Polycheles typhlops: an exception or the species that strengthens a hypothesis?}

Polycheles typhlops was the single deep-dwelling species in this study which did not present seasonal behaviour in its reproductive processes. The reasons behind this behaviour may well be related to one of the characteristics present in all Polychelidae species, i.e. that adults and larvae are blind (Bernard 1953, Beaubrun 1978). Other differential characteristics of this species in comparison with its depth-related species have been shown in Table 2 .

Historically, differential and reduced food availability has been considered to be one of the main factors affecting the biological traits and community and population structure of the deep-water and deep-sea species (Gage 1991, Gage \& Tyler 1991, Levin et al. 1994, Puig et al. 2001). However, Childress (1995, and references therein) postulates the light hypothesis; instead of an adaptation to a reduced food availability, adaptation to low levels of light in a deep-water environment can account for the decline in the metabolic rates of midwater animals having visual-feeder habits. Light could be involved in the evolution of different locomotive and predatory capacities at different depths. Several studies show how the metabolism of midwater fishes, crustaceans and cephalopods decreases down to $1000 \mathrm{~m}$. Below this depth the metabolism ceases to decline, due to essential absence of light (Childress 1995, Seibel et al. 2000). Childress (1995) and Seibel et al. (2000) proposed that light plays an important role not only in species distribution, but also in the evolutionary processes of these midwater animals. They hypothesised that the lower predator-prey interaction 
related to the low light intensity at greater depths is the cause of this decline in metabolic rates. In invertebrate animals with no vision, such as chaetognaths in which the interaction between predator-prey does not play a major role in feeding behaviour, no decreases of metabolic rates versus depth gradient were found (Thuesen \& Childress 1993).

Polycheles typhlops does not follow any of the trends mentioned until now. Being blind must have a significant effect on its feeding behaviour. In fact, we assume that this species is a non-visual feeder because only scavenging habits have been described (Cartes \& Abelló 1992). It feeds on organic detritus found in sediment and no active feeding has been described. Stereomatis sculpta and S. nana, 2 other deep-sea blind species of the same family, also have continuous reproductive periods (Wenner 1979). S. sculpta is also distributed in the northwestern Mediterranean (Abelló \& Cartes 1992, Cartes \& Sardà 1992), but no information on year-round reproductive data is available at present. Other shallow-dwelling species of this infraorder (Palinura), such as species of the genus Palinurus, and in particular the coastal and shelf dwelling species $P$. elephas, show a highly seasonal reproductive cycle (Morgan 1980, Hunter 1999). None of these coastal and shallow species are blind.

Several questions have arisen from our collective data: is the light hypothesis proposed by Childress (1995), i.e. that metabolic rates decline with depth due to a light adaptation, also related to reproductive processes? Is a visual trophic relationship linked with the food availability related to this process? Why is the only species without a clear seasonality to its reproductive processes blind? Why is this species the only one with differently coloured gonads and eggs, while all the others follow a similar trend in relation to the colour of their gonads and exoskeletons (Company 1995)? However the main question is: if, as mentioned in the first section of this discussion, the available energy at middle-slope depths does not allow species to undertake year-round reproductive processes, why does Polychele typhlops do this?

The answer may lie in the feeding behaviour of this species. The energy needed for female gonad storage may be independent of the seasonal signal of the matter sinking from the photic zones due to its scavenging behaviour, which means that this species would be able to allocate enough energy through the entire year. Larvae are also blind, which means that the release of these larvae would not be necessarily linked with a favourable season for them to be able to catch prey.

We assume that all the trends mentioned in the 2 previous sections are yet more valid when taking into account the reproductive behaviour described for Polycheles typhlops. As discussed, reduced food availability affects the duration of the reproductive periods, but somehow this reduction only affects the visual feeder species due to their high level of dependence on a predator-prey relationship. Thus, the species will have to adapt to reproduce in the season of the year when their prey is more abundant in order to store energy for their gonads or in order to release their larvae in the most favourable season when their larvae will be able to see their prey in the water column. Despite this reduction of the food availability at the middle-slope habitats, species with the unique feeding characteristics of P. typhlops will be able to reproduce throughout the year. In this regard, Blake (1993) and Tyler et al. (1993), concerning the reproduction characteristics of several deep-water and deep-sea polychaete species and 2 deep-sea seastars, would corroborate the results presented here. These authors hypothesised that surface deposit feeders would be more likely to exhibit seasonality in their reproduction than sub-surface deposit feeders.

Our results, including those related to the blind species Polycheles typhlops, lead us to assume that food availability and phylogenetic traits control the reproductive processes of the decapod crustaceans dwelling in the continental margin of the Mediterranean, but that adaptation of the species' reproductive processes to a specific habitat are ultimately controlled by light through its effect on the feeding modality of the species.

Although recent work postulates that the deep sea is much more physically and biochemically variable than previously thought (Gage \& Tyler 1991, Gage 1994, Smith et al. 2002), the historical concept of the deep sea being highly stable can be accepted when compared with terrestrial or coastal environments. In this regard, Childress (1995) pointed out that one of the main reasons for the generalised physiological response of animals living in midwater habitats is that they are essentially exposed to the same and seasonally constant environmental conditions. This conclusion can also be applied to the generalised trend found here regarding the reproductive processes of the continental slope-dwelling species of decapods.

In conclusion, the understanding of deep-sea ecological processes needs long-term data, and too much of our knowledge is hypothetical. Larval behaviour is one of the least known processes of deep-sea species biology (Tyler \& Young 1998). Thus, we were not able to fully interpret the information in this study. For example, the timing of the reproductive period of each of the middle-slope species could well be linked with the overall larval behaviour, including trophism and settlement behaviour. If, for instance, we knew which larvae have direct development with no pelagic stages or which ones have free spawning planktotrophy, this would greatly help the interpretation of the timing of the reproductive processes shown here. 
Acknowledgements. This study was supported by the European Commission (projects MED 92/008 to F.S. and MAS2-CT93-0053 and MAS3-CT95-0037 to A.P.) and by the Spanish Interdepartmental Commission for Science and Technology (CICiT) (project MAR90-0757 to F.S.). The authors wish to thank the crews of the fishing boats 'Maireta II' and 'Maireta III', and RVs 'García del Cid' and 'Hesperides' for their assistance and support during surveys. Comments on the data in this manuscript made by I. Palomera were very useful.

\section{LITERATURE CITED}

Abelló P (1989a) Reproductive biology of Macropipus tuberculatus (Roux, 1830) (Brachyura: Portunidae) in the northwestern Mediterranean. Ophelia 30:47-53

Abelló P (1989b) Reproduction and moulting in Liocarcinus depurator (Linnaeus, 1758) (Brachyura: Portunidae) in the Northwestern Mediterranean sea. Sci Mar 53:127-134

Abelló P, Cartes JE (1992) Population characteristics of the deep-sea lobsters Polycheles typhlops and Stereomastis sculpta (Decapoda: Polychelidae) in a bathyal mud community of the Mediterranean Sea. Mar Biol 114:109-117

Abelló P, Carbonell A, Torres P (2002) Biogeography of epibenthic crustaceans on the shelf and upper slope off the Iberian Peninsula Mediterranean coasts: implications for the establishment of natural management areas. Sci Mar 66:183-198

Asper VL, Deuser WG, Knauer GA, Lohrenz SE (1992) Rapid coupling of sinking particle fluxes between surface and deep ocean waters. Nature 357:670-672

Beaubrun PC (1978) Crustacés décapodes marcheurs des côtes marocaines (Sections des Astacidea, Eryonidea, Thalassinidea). Bulletin de l'Institut Scientifique, Rabat 3:1-110

Bernard F (1953) Decapoda Eryonidae (Eryoneicus et Willemoesia). Dana-Report 37, The Carlsberg Foundation, Copenhagen

Bishop JDD, Shalla SH (1994) Discrete seasonal reproduction in an abyssal peracarid crustacean. Deep-Sea Res I 41: 1789-1800

Blake JA (1993) Life history analysis of 5 dominant infaunal polychaete species from the continental slope off north Carolina. J Mar Biol Assoc UK 73:123-141

Campos-Creasy LS, Tyler PA, Gage JD, John WG (1994) Evidence for coupling the vertical flux of phytodetritus to the diet and season life history of the deep-sea echinoid Echinus affinis. Deep-Sea Res I 41:369-388

Cartes JE (1998) Dynamics of the bathyal Benthic Boundary Layer in the north-western Mediterranean: depth and temporal variations and their possible connections within deep-sea trophic webs. Prog Oceanogr 41:111-139

Cartes JE, Abelló P (1992) Comparative feeding habits of polychelid lobsters in the Western Mediterranean deepsea communities. Mar Ecol Prog Ser 84:139-150

Cartes JE, Sardà F (1992) Abundance and diversity of decapod crustaceans in the deep-Catalan Sea (Western Mediterranean). J Nat Hist 26:1305-1323

Cartes JE, Elizalde M, Sorbe JC (2001) Contrasting lifehistories, secondary production, and trophic structure of Peracarid assemblages of the bathyal suprabenthos from the Bay of Biscay (NE Atlantic) and the Catalan Sea (NW Mediterranean). Deep-Sea Res I 48:2209-2232

Childress JJ (1995) Are there physiological and biochemical adaptations of metabolism in deep-sea animals? Trends Ecol Evol 10:30-36

Childress JJ, Somero GN (1979) Depth related enzymatic activities in muscle, brain and heart of deep-living pelagic marine teleosts. Mar Biol 52:273-283

Childress JJ, Taylor SM, Cailliet GM, Price MH (1980) Patterns of growth, energy utilization and reproduction in some meso- and bathypelagic fishes off Southern California. Mar Biol 61:27-40

Childress JJ, Cowles DL, Favuzzi JA, Mickel TJ (1990) Metabolic rates of benthic deep-sea decapod crustaceans decline with increasing depth primarily due to the decline in temperature. Deep-Sea Res 37:929-949

Company JB (1995) Comparative study of the biological trends of crustacean decapod on the Catalan Sea (Mediterranean contiental margin). PhD dissertation, University of Barcelona

Company JB, Sardà F (1997) Reproductive patterns and population characteristics in 5 deep-water pandalid shrimps in the Western Mediterranean along a depth gradient (150-1100 m). Mar Ecol Prog Ser 148:49-58

Company JB, Sardà F (1998) Metabolic rates and energy content of deep-sea benthic decapod crustaceans in the Western Mediterranean Sea. Deep-Sea Res I 45:1861-1880

Company JB, Sardà F (2000) Growth parameters of deepwater decapod crustaceans in the Northwestern Mediterranean Sea: a comparative approach. Mar Biol 136:79-90

Company JB, Cartes JE, Sardà F (2001) Biological patterns and near-bottom population characteristics of 2 pasiphaeid decapod crustacean species, Pasiphaea sivado and P. multidentata, in the north-western Mediterranean Sea. Mar Biol 139:61-73

Cowles DL, Childress JJ, Wells ME (1991) Metabolic rates of midwater crustaceans as a function of depth of occurrence off the Hawaiian Islands: Food availability as a selective factor? Mar Biol 110:75-83

Demestre M (1990) Biologia pesquera de la gamba Aristeus antennatus (Risso, 1816). PhD dissertation, University of Barcelona

Demestre M, Fortuño JM (1992) Reproduction of the deepwater shrimp Aristeus antennatus (Decapoda: Dendrobranchiata). Mar Ecol Prog Ser 84:41-51

Eckelbarger KJ, Watling L (1995) Role of phylogenetic constraints in determining reproductive patterns in deep-sea invertebrates. Invertebr Biol 114:256-269

Gage JD (1991) Biological rates in the deep sea: A perspective from studies on processes in the benthic boundary layer. Rev Aquat Sci 5:49-100

Gage JD (1992) Benthic secondary production in the deepsea. In: Rowe GT, Pariente V (eds) Deep-sea food chains and the global carbon cycle. Kluwer Academic Publishers, Dordrecht, p 183-198

Gage JD (1994) Recruitment ecology and age structure of deep-sea invertebrate populations. In: Young CM, Eckelbarger KJ (eds) Reproduction, larval biology, and recruitment of the deep-sea benthos. Columbia University Press, New York, p 223-242

Gage JD, Tyler PA (1991) Deep-sea biology: a natural history of organisms at the deep-sea floor. Cambridge University Press, London

Giangrande A (1997) Polychaete reproductive patterns, life cycles and life histories: an overview. Oceanogr Mar Biol Annu Rev 35:323-386

Giangrande A, Geraci S, Belmonte G (1994) Life-cycle and life-history diversity in marine invertebrates and the implications in community dynamics. Oceanogr Mar Biol Annu Rev 32:305-333

Gooday AJ (1988) A response by benthic Foraminifera to the deposition of phytodetritus in the deep sea. Nature 332 $70-73$ 
Gooday AJ (2002) Biological responses to seasonally varying fluxes of organic matter to the ocean floor: a review. J Oceanogr 58:305-332

Harrison K (1988) Seasonal reproduction in deep-sea Crustacea (Isopoda: Asellota). J Nat Hist 22:175-197

Heussner S, Ratti C, Carbonne J (1990) The PPS 3 times-series sediment trap and the trap sample processing techniques used during the ECOMARGE experiment. Cont Shelf Res 10:943-958

Hopkins TS (1985) Physics of the Sea. In: Margalef R (ed) Key environments: western Mediterranean. Pergamon Press, New York, p 100-125

Hunter E (1999) Biology of the European spiny lobster, Palinurus elephas (Fabricius, 1787) (Decapoda. Palinuridea). Crustaceana 72:545-566

Levin LA, Gage JD (1998) Relationship between oxygen, organic matter and diversity of bathial macrofauna. DeepSea Res II 45:129-163

Levin LA, Plaia GR, Huggett CL (1994) The influence of natural organic enhancement on life histories and community structure of bathyal polychaetes. In: Young CM, Eckelbarger KJ (eds) Reproduction, larval biology, and recruitment of the deep-sea benthos. Columbia University Press, New York, p 261-283

Margalef R (1986) Ecología. Ediciones Omega, Barcelona

Maynou F, Cartes JE (2000) Community structure of bathyal decapod crustacean assemblages off the Balearic Islands (south-western Mediterranean). J Mar Biol Assoc UK 80: 789-798

Merrett NR, Marshall NB (1981) Observations on the ecology of deep-sea bottom living fishes collected off northwest Africa $\left(08-27^{\circ} \mathrm{N}\right)$. Prog Oceanogr 9:185-244

Morgan GR (1980) Population dynamics of spiny lobsters. In: Cobb JS, Phillips BF (eds) The biology and management of lobsters, Vol II. Academic Press, New York, p 189-217

Mortlock RA, Froelich PN (1989) A simple method for the rapid determination of biogenic opal in pelagic marine sediments. Deep-Sea Res 36:1415-1426

Orton JH (1920) Sea temperature, breeding and distribution in marine animals. J Mar Biol Assoc UK 12:339-366

Puig P, Palanques A (1998a) Nepheloid structure and hydrographic control in the Barcelona continental margin, northwestern Mediterranean. Mar Geol 149:39-54

Puig P, Palanques A (1998b) Temporal variability and composition of settling particle fluxes on the Barcelona continental margin. J Mar Res 56:639-654

Puig P, Company JB, Sardà F, Palanques A (2001) Responses of deep-water shrimp population to the presence of intermediate nepheloid layers on continental margins. DeepSea Res I 48:2195-2207

Ramirez Llodra E, Tyler PA, Copley JTP (2000) Reproductive biology of 3 caridean shrimp, Rimicaris exoculata, Chorocaris chacei and Mirocaris fortunata (Caridea:Decapoda), from hydrothermal vents. J Mar Biol Assoc UK 80:473-484

Ramirez-Llodra E, Tyler PA, Billett DSM (2002) Reproductive biology of porcellanasterid asteroids from 3 abyssal sites in the northeast Atlantic with contrasting food input. Mar Biol 140:773-788

Rodríguez SR, Ojeda FP, Inestrosa NC (1993) Settlement of benthic marine invertebrates. Mar Ecol Prog Ser 97: 193-207

Rokop FJ (1974) Reproductive patterns in the deep-sea benthos. Science 186:743-745

Rokop FJ (1977) Patterns of reproduction in the deep-sea

Editorial responsibility: Otto Kinne (Editor),

Oldendorf/Luhe, Germany benthic crustaceans: a re-evaluation. Deep-Sea Res 24: 683-691

Rotllant G, Charmantier-Daures M, Charmantier G, Anger K, Sardà F (2001) Effect of diet on Nephrops norvegicus (L.) larval and postlarval development, growth, and elemental composition. J Shellfish Res 20:347-352

Rowe GT (1983) Deep-sea biology: the sea, Vol 8. John Wiley \& Sons, New York

Sardà F, Cartes JE (1997) Morphological features and ecological aspects of early juvenile specimens of the aristeid shrimp Aristeus antennatus (Risso, 1816). Mar Freshw Res 48:73-77

Sardà F, Lleonart J (1993) Evaluation of the Norway lobster (Nephrops norvegicus, L.) resource of the serola bank off Barcelona (western Mediterranean). Sci Mar 57:191-197

Sardà F, Cartes JE, Company JB (1994) Spatio-temporal variations in megabenthos abundance in 3 different habitats of the Catalan deep-sea (Western Mediterranean). Mar Biol 120:211-219

Sardà F, Cartes JE, Company JB, Albiol T (1998) A modified commercial trawl used to sample deep-sea megabenthos. Fish Sci 64:492-493

Seibel B, Thuesen EV, Childress JJ (2000) Light-limitation on predator-prey interactions: consequences for metabolism and locomotion of deep-sea cephalopods. Biol Bull 198: $284-298$

Smith KL (1987) Food energy supply and demand: A discrepancy between particulate organic carbon flux and sediment community oxygen consumption in the deep ocean. Limnol Oceanogr 32:201-220

Smith KL Jr, Baldwin RJ, Karl DM, Boetius A (2002) Benthic community responses to pulses in pelagic food supply: North Pacific Subtropical Gyre. Deep-Sea Res I 49:971-990

Somero GN, Siebenaller JF, Hochachka PW (1983) Biochemical and physiological adaptations of deep-sea animals. In: Rowe GT (ed) Deep-sea biology: the sea, Vol 8. John Wiley \& Sons, New York, p 261-330

Sumida PYG, Tyler PA, Lampitt RS, Gage JD (2000) Reproduction, dispersal and settlement of the bathyal ophiuroid Ophiocten gracilis in the NE Atlantic Ocean. Mar Biol 137: $623-630$

Thorson G (1950) Reproductive and larval ecology of marine bottom invertebrates. Biol Rev 25:1-45

Thuesen EV, Childress JJ (1993) Enzymatic activities and metabolic rates of pelagic chaetognaths: lack of depthrelated declines. Limnol Oceanogr 38:935-948

Tyler PA (1988) Seasonality in the deep sea. Oceanogr Mar Biol Annu Rev 26:227-258

Tyler PA, Young CM (1998) Temperature and pressure tolerances in dispersal stages of the genus Echinus (Echinodermata: Echinoidea): prerequisites for deep-sea invasion and speciation. Deep-Sea Res II 45:253-277

Tyler PA, Gage JD, Paterson GJL, Rice AL (1993) Dietary constraints on reproductive periodicity in 2 sympatric deepsea astropectinid seastars. Mar Biol 115:267-277

Tyler PA, Campos-Creasy LS, Giles LA (1994) Environmental control of quai-continuous and seasonal reproduction in deep-sea benthic invertebrates. In: Young CM, Eckelbarger KJ (ed) Reproduction, larval biology, and recruitment of the deep-sea benthos. Columbia University Press, New York, p 158-178

Wenner EL (1979) Some aspects of the biology of deep-sea lobsters of the family Polychelidae (Crustacea, Decapoda) from the western North Atlantic. Fish Bull 77:435-444

Submitted: December 11, 2002; Accepted: July 17, 2003

Proofs received from author(s): September 30, 2003 